\title{
Ruptured abdominal aortic aneurysm identified on point-of-care ultrasound in the emergency department
}

\author{
Omar Diaz and Wesley Eilbert
}

\begin{abstract}
Background: Ruptured abdominal aortic aneurysm (AAA) is a highly lethal condition which requires rapid identification and treatment to improve the chance of survival. Computed tomography is the diagnostic modality of choice for ruptured AAA though it is time-consuming and often requires movement of the patient out of the emergency department (ED). Point-of-care ultrasound in the ED has excellent sensitivity and specificity for the detection of AAA, though less is known about its use to diagnose AAA rupture. We report a case of ruptured AAA identified on ultrasound performed at the bedside in the ED.

Case presentation: A 77-year-old woman on warfarin with a known AAA presented to our ED with 2 days of epigastric abdominal pain. Point-of-care ultrasound revealed several findings suggestive of rupture of the AAA, which was confirmed on computed tomography. The patient was subsequently taken for emergent operative repair of the AAA and was later discharged from the hospital.

Conclusions: Characteristics suggestive of AAA rupture may be seen on ultrasound. As ED physicians become more familiar with the use of point-of-care ultrasound in the evaluation of abdominal pain, identification of these characteristics may aid in the rapid diagnosis of AAA rupture.
\end{abstract}

Keywords: Abdominal aortic aneurysm, Ruptured abdominal aortic aneurysm, Emergency ultrasound, Bedside ultrasound, Point-of-care ultrasound

\section{Background}

Rupture of an abdominal aortic aneurysm (AAA) is often lethal, with a mortality of $85-90 \%$ [1]. Delays in the diagnosis and treatment are known to be a major contributor to the lethality of this condition [2]. A palpable abdominal mass may be present on physical exam, though this finding has a wide range of sensitivity from $29-76 \%$ [3]. With point-of-care ultrasound part of the core emergency medicine curriculum in the United States, emergency physicians have become quite adept at using this imaging modality to diagnose AAA [4].

\footnotetext{
* Correspondence: weilbert@uic.edu

Department of Emergency Medicine, University of Illinois at Chicago, College of Medicine, Room 469, COME 1819 West Polk St, Chicago, IL 60612, USA
}

However, less is known about the use of point-of-care ultrasound to diagnose AAA rupture. We report a case of a ruptured AAA identified by point-of-care ultrasound in the emergency department (ED).

\section{Case presentation}

A 77-year-old woman presented to our ED complaining of non-radiating epigastric abdominal pain starting the previous day and becoming severe approximately $2 \mathrm{~h}$ before coming to the hospital. She had some associated non-bloody emesis. Her past medical history was significant for hypertension, peripheral vascular disease, coronary artery disease, chronic kidney disease, and chronic obstructive pulmonary disease with an extensive history of smoking. She was taking warfarin for protein $\mathrm{S}$

(c) The Author(s). 2020 Open Access This article is licensed under a Creative Commons Attribution 4.0 International License, which permits use, sharing, adaptation, distribution and reproduction in any medium or format, as long as you give appropriate credit to the original author(s) and the source, provide a link to the Creative Commons licence, and indicate if changes were made. The images or other third party material in this article are included in the article's Creative Commons licence, unless indicated otherwise in a credit line to the material. If material is not included in the article's Creative Commons licence and your intended use is not permitted by statutory regulation or exceeds the permitted use, you will need to obtain permission directly from the copyright holder. To view a copy of this licence, visit http://creativecommons.org/licenses/by/4.0/ The Creative Commons Public Domain Dedication waiver (http://creativecommons.org/publicdomain/zero/1.0/) applies to the data made available in this article, unless otherwise stated in a credit line to the data. 
deficiency complicated by previous deep venous thromboses. She had a known infrarenal AAA measuring 4.4 $\mathrm{cm}$ in diameter seen on computed tomography (CT) 3 months earlier. The AAA had not changed in size over the previous 4 years. On arrival she appeared uncomfortable, though in no apparent distress. Her blood pressure was $142 / 113 \mathrm{mmHg}$, heart rate $60 \mathrm{bpm}$, respiratory rate $15 \mathrm{bpm}$, temperature 35.8 degrees Celsius, and pulse oximetry $97 \%$ on room air. She was noted to be tender to palpation in the epigastrium without guarding, and no masses were appreciated in her abdomen.

A point-of-care ultrasound was performed revealing an AAA measuring approximately $6 \mathrm{~cm}$ in diameter (Fig. 1). There was an inhomogeneous appearance of the luminal thrombus of the aneurysm. A hypoechoic area was identified which caused a discontinuity of the aneurysm's luminal thrombus and outer wall and extended into the para-aortic space, suggestive of aneurysmal rupture. Laboratory values were significant for creatinine $2.0 \mathrm{mg} / \mathrm{dL}$, international normalized ratio 1.4 , and hemoglobin $10.6 \mathrm{~g} /$ L. A review of her previous laboratory values noted her hemoglobin had been $13.0 \mathrm{~g} / \mathrm{L}$ approximately 2 months prior. $\mathrm{CT}$ of the abdomen and pelvis was performed confirming the presence of an infrarenal AAA measuring 6.4 $\mathrm{cm}$ in diameter (Fig. 2). The CT also revealed a large right retroperitoneal hematoma adjacent to the AAA with attenuation suggesting subacute hemorrhage.

A transfusion of 2 units of packed red blood cells was started in the ED, and the vascular surgery service was consulted. The patient was taken emergently to the operating room where the ruptured AAA was repaired using a polyester graft. After a difficult postoperative

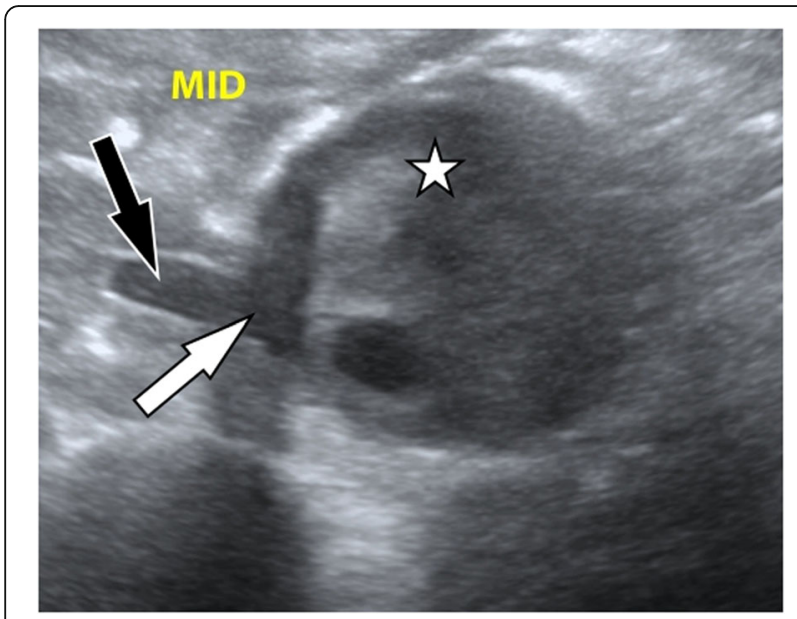

Fig. 1 Ultrasonographic transverse view of the abdominal aortic aneurysm with an inhomogeneous appearance of the luminal thrombus (star), a focal disruption of the luminal thrombus and the outer wall of the aneurysm (white arrow), and a para-aortic hypoechoic area (black arrow)

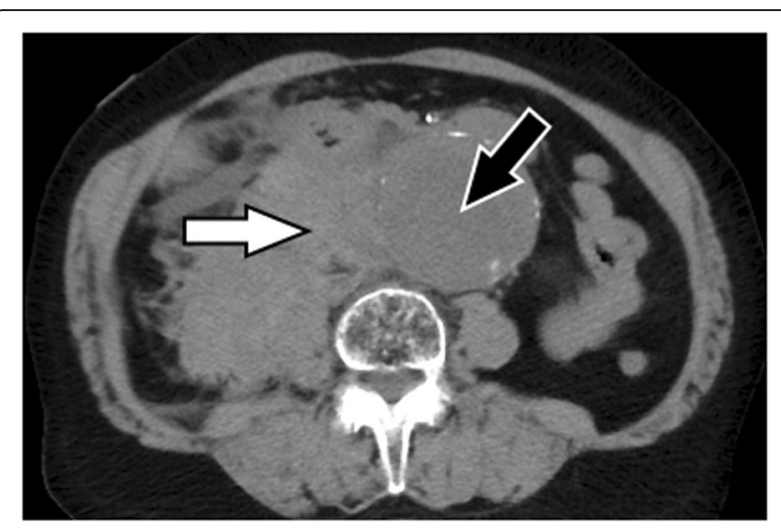

Fig. 2 Noncontrast computed tomography of the abdominal aortic aneurysm (black arrow) with an adjacent subacute retroperitoneal hemorrhage (white arrow)

course, the patient was eventually discharged to a rehabilitation facility 5 weeks later.

\section{Discussion}

The most commonly used definition of an AAA is a maximum infrarenal abdominal aortic diameter greater than 3 $\mathrm{cm}$ on ultrasound or CT imaging [5]. While rare under the age of 50, the prevalence of AAA over age 65 is $5-10 \%$ in men and $0.5-1.3 \%$ in women, with increasing prevalence with each decade of life [6, 7]. Risk factors for AAA include smoking, hypertension, white race, atherosclerotic disease, and a family history of the disorder [1]. The risk of rupture of AAAs less than $4 \mathrm{~cm}$ diameter is negligible; however, this risk increases exponentially after reaching a diameter of $5 \mathrm{~cm}$ to an annual rupture risk of $30-50 \%$ for those larger than $8 \mathrm{~cm}$ [8]. Unfortunately, most AAAs are asymptomatic until they rupture. It is estimated that ruptured AAA accounts for $1 \%$ of all deaths of men over age 65 and that $50 \%$ of patients with a ruptured AAA will die before reaching the hospital $[9,10]$.

Rapid identification and treatment of ruptured AAA is paramount to improving survival, though its diagnosis often remains elusive. It is estimated that only $30-50 \%$ of cases present with the classic triad of abdominal pain, hypotension, and pulsatile mass [3]. In 1992, Martin et al. found that $30 \%$ of cases were initially misdiagnosed, often as renal colic, diverticulitis, or gastrointestinal hemorrhage [11]. In 1994, Lederle et al. reported that the diagnosis of ruptured AAA was missed in $61 \%$ of cases presenting to internists and was only identified when hemodynamic compromise occurred [12].

CT is the diagnostic modality of choice for ruptured AAA, though point-of-care ultrasound is more readily available in most EDs. ED ultrasound screening for ruptured AAA has been found to reduce the time to diagnosis and improve patient outcomes [13]. ED point-ofcare ultrasound has a sensitivity of $99 \%$ and specificity of 
Table 1 Sonographic findings with abdominal aortic aneurysm rupture

Deformation of aneurysmal shape
Inhomogeneous appearance of the luminal thrombus
Focal discontinuity of the thrombus layer
A floating intraluminal thrombus layer
Focal disruption of the outer aneurysmal wall
A para-aortic hypoechoic area
Retroperitoneal hematoma
Hemoperitoneum

98\% for the detection of AAA, though it is much less useful in identifying rupture. This is due to the fact that most (88\%) AAAs rupture into the retroperitoneal space, where ultrasound visualization is limited [3]. In 2005, Catalano et al. described 8 sonographic findings of AAA rupture in 29 patients (Table 1) [14]. Four of these findings were present in our patient. Catalano et al. also described a contrast-enhanced bedside ultrasound using an intravenous microbubble contrast agent to improve the accuracy of diagnosing ruptured AAAs [15]. Some authors have advocated immediate operative repair of AAAs if rupture is identified on bedside ultrasound, especially in hypotensive patients [16]. This practice would bypass the time-consuming task of CT scanning.

Emergent operative repair has been the traditional treatment of ruptured AAAs, though endovascular repair has become another treatment option, even in unstable patients [17]. Regardless of the method of repair chosen, rapid identification of this highly lethal condition is of utmost importance. As emergency physicians become increasingly proficient with the use of bedside ultrasound, its role in the diagnosis of ruptured AAA will likely increase.

\section{Acknowledgements}

We are indebted to Elizabeth Pearson and Joseph Eilbert for their assistance in the preparation of this manuscript.

\section{Authors' contributions}

OD provided the information for the case report, performed the preliminary literature search, and assisted in the writing of the manuscript. WE performed the definitive literature search and assisted in the writing of the manuscript. The authors read and approved the final manuscript.

\section{Funding}

None.

\section{Availability of data and materials}

Data sharing not applicable to this article as no data sets were generated or analyzed during the current study.

Ethics approval and consent to participate Not applicable.

Consent for publication

Not applicable.

\section{Competing interests}

The authors declare that they have no competing interests.

Received: 26 February 2020 Accepted: 14 April 2020

Published online: 14 May 2020

References

1. Kent KC. Clinical practice. Abdominal aortic aneurysms. N Engl J Med. 2014; 371(22):2101-8.

2. Sebesta P, Klika T, Zdrahal P, Kramar J. Ruptured abdominal aortic aneurysm: role of initial delay on survival. J Mal Vasc. 1998;23(5):361-7.

3. Lech C, Swaminathan A. Abdominal aortic emergencies. Emerg Med Clin North Am. 2017;35(4):847-67.

4. Rubano E, Mehta N, Caputo W, Paladino L, Sinert R. Systematic review: emergency department bedside ultrasonography for diagnosing suspected aortic aneurysm. Acad Emerg Med. 2013;20(2):128-38.

5. Gollege J. Abdominal aortic aneurysm: update on pathogenesis and medical treatments. Nat Rev Cardiol. 2019;16(4):225-42.

6. Genovese EA, Fonio P, Floridi C, Macchi M, Maccaferri A, lanora AA, et al. Abdominal vascular emergencies: US and CT assessment. Crit Ultrasound J. 2013:5(Suppl 1):S10.

7. Preventative Services Task Force US. Screening for abdominal aortic aneurysm: recommendation statement. Ann Intern Med. 2005;142(3):198202.

8. Brewster DC, Cronenwett JL, Hallett JW, Johnston KW, Krupski WC, Matsumura JS, et al. Guidelines for the treatment of abdominal aortic aneurysms. Report of a subcommittee of the Joint Council of the American Association of Vascular Surgery and Society for Vascular Surgery. J Vasc Surg. 2003;37(5):1106-17.

9. Howard DP, Banerjee A, Fairhead JF, Handa A, Silver LE, Rothwell PM, et al. Age-specific incidence, risk factors and outcome of acute abdominal aneurysms in a defined population. Br J Surg. 2015;102(8):907-15.

10. Lewiss RE, Egan D, Shreves A. Vascular abdominal emergencies. Emerg Med Clin N Am. 2011;29(2):253-72.

11. Marston WA, Ahlquist R, Johnson G, Meyer AA. Misdiagnosis of ruptured abdominal aortic aneurysms. J Vasc Surg. 1992;16(1):17-22.

12. Lederle FA, Parenti CM, Chute EP. Ruptured abdominal aortic aneurysm: the internist as a diagnostician. Am J Med. 1994;96(2):163-7.

13. Plummer D, Clinton J, Matthew B. Emergency department ultrasound improves time to diagnosis and survival in ruptured abdominal aortic aneurysm [Abstract]. Acad Emerg Med. 1998;5(5):417.

14. Catalano O, Siani A. Ruptured abdominal aortic aneurysm. Categorization of sonographic findings and report of 3 new signs. J Ultrasound Med. 2005; 24(8):1077-83

15. Catalano O, Lobianco R, Cusati B. Contrast-enhanced sonography for diagnosis of ruptured abdominal aortic aneurysm. AJR Am J Roentgenol. 2005;184(2):423-7.

16. Bhatt S, Dogra VS. Catastrophes of abdominal aorta: sonographic evaluation. Ultrasound Clin. 2008;3(1):83-91.

17. Spencer T, Juyia R, Parks R. Case series of patients with ruptured abdominal aortic aneurysm. West J Emerg Med. 2015;16(3):367-71.

\section{Publisher's Note}

Springer Nature remains neutral with regard to jurisdictional claims in published maps and institutional affiliations.

Ready to submit your research? Choose BMC and benefit from:

- fast, convenient online submission

- thorough peer review by experienced researchers in your field

- rapid publication on acceptance

- support for research data, including large and complex data types

- gold Open Access which fosters wider collaboration and increased citations

- maximum visibility for your research: over $100 \mathrm{M}$ website views per year

At BMC, research is always in progress.

Learn more biomedcentral.com/submissions 